Agogué, M., Berthet, E., Fredberg, T., Le Masson, P., Segrestin, B., Stoetzel, Wiener, M., and Yström, A. (2017). "Explicating the role of innovation intermediaries in the "unknown": a contingency approach." Journal of Strat and Management, 10, (1), pp. 19-39.

\title{
Explicating the role of innovation intermediaries in the "unknown": A contingency approach
}

\begin{abstract}
Innovation intermediaries have become key actors in open innovation contexts. Research has improved our understanding of the managerial challenges inherent to intermediation in situations in which problems are rather well-defined. Yet, in some open innovation situations, the relevant actor networks may not be known, there may be no clear common interest, or severe problems may exist with no legitimate common place where they can be discussed. This paper contributes to the research on innovation intermediaries by showing how intermediaries address managerial challenges related to a high degree of unknown. We draw upon the extant literature to highlight the common core functions of different types of intermediaries. We then introduce the "degree of unknown" as a new contingency variable for the analysis of the role of intermediaries for each of these core functions. We illustrate the importance of this new variable with four empirical case studies in in different industries and countries in which intermediaries are experiencing situations of high level of unknown. We highlight the specific managerial principles that the four intermediaries applied in creating an environment for collective innovation. Therefore, we clarify what intermediation in the unknown may entail.
\end{abstract}

Keywords: innovation intermediaries; open innovation; collaborative innovation; degree of unknown; innovation management 
Scholars have recognised the role and the growing importance of intermediaries in innovation (Howells, 2006) as change agents for open innovation. Increasing technological complexities, maturing markets, and global competition require that knowledge and creative brainpower be sought not merely internally within a firm, but also externally in creative communities and from external experts. Innovation intermediaries can have various missions. They can support brokering for either problem solving (Hargadon \& Sutton, 1997, Gianiodis et al., 2010) or technology transfer (Bessant \& Rush, 1995). They can also play an active role in networking among dispersed but complementary organisations (Klerkx \& Leeuwis, 2009). Whatever their mission is, intermediaries "connect companies to external sources or recipients of innovation and mediate their relationships with those actors" (Nambisan et al., 2012). They facilitate the identification of external knowledge providers and make external knowledge accessible. In a similar manner, they come into play when transfer to the market is the only means of commercialisation because internally developed knowledge or ideas cannot be utilised for the company's proprietary products or services. Intermediaries act as agents that improve connectivity within and among innovation networks (Stewart \& Hyysalo, 2008), which is of high importance with regard to systemic innovations (van Lente et al., 2003).

Research has improved our understanding of the managerial challenges inherent in exploratory intermediation. For instance, it is necessary to build trust among participants and to coordinate contributors when the outputs of the collaboration are uncertain, just as in other types of collaborative innovation (Fawcett et al., 2012). Similarly, there is a need to organise specific learning processes and ensure that there is sufficient consensus among partners (van Lente et al., 2003) when the needed knowledge does not already exist. Significantly, the recent literature has stressed that the role of intermediaries can be critical to the exploration of new opportunities and the development of new ways to address shared issues, such as sustainability and environmental issues (Michaels, 2009). For instance, intermediaries can initiate change (Lynn et al. 1996; Callon 1994), build networks (McEvily \& Zaheer, 1999) and determine "where to look in the first place" (Howells, 2006, p. 723). It is important to note that there is a significant difference between being an intermediary in cases where problems are known, actors can be recognized and there is sufficient knowledge available to solve the problems (most likely to result in more incremental innovations), and cases where the problems are ill-defined, the role of actors is not given, and where not even the art of 
knowledge needed, is known (this is most likely the case at the outset of a process that generates more radical innovations).

Research has emphasised that intermediaries face increasing difficulties in addressing these challenges (Birkinshaw et al., 2011; Sieg et al., 2010). Notably, their activities get more diverse and more complex, which implies that their role and position within the innovation system becomes unclear and even sometimes problematic (Klerkx \& Leeuwis, 2009). The higher complexity of the role and activities of intermediaries relies on the fact that they face increasingly emergent and/or ill-defined situations where learning processes are necessary (Klerkx, Aarts \& Leeuwis, 2010). In line with this, recent works have characterized new forms of intermediaries such as "architects of the unknown" (Agogué, Le Masson \& Yström, 2013) or "colleges of the unknown" (Le Masson et al., 2012). They suggest that specific management principles for intermediation might be needed.

To understand the increasing complexity of the activities and roles of innovation intermediaries, we propose to introduce the "degree of unknown" as a new contingency variable. This introduction leads to a new framework of analysis. For example, situations of low degree of unknown occur when actors in collaborative innovation endeavours are attracted by a clear common goal, which an intermediary can express and communicate, or when conflicting stakeholders can work together because the necessity and expectations are sufficiently high for all. Such situations are typically also connected with a low degree of information obscurity and more incremental innovations. However, what if there is no common goal or common vision and little clarity of how the innovation field is progressing? What if the intermediary alone cannot identify a common goal or common problem? What if there is no legitimate place to which an intermediary can invite potential stakeholders to begin to work together to create a common goal? In this paper, we characterize such situations as being of high degree of unknown.

Our goal in this paper is to better define the role of innovation intermediaries when the degree of unknown is high. We address the following research questions: What are the managerial challenges met by innovation intermediaries in situations of high degree of unknown? And how can they potentially address these challenges? 
The following sections are organised as follows: we first review the literature on intermediaries to highlight common core functions of the different types of intermediaries. Then, we introduce the "degree of unknown" as a new dimension for analysing the role of intermediaries. We analyse the conditions under which the intermediaries can fulfil their core functions when the degree of unknown is very high. We present four empirical cases in which intermediaries face situations of high level of unknown and address the related managerial challenges. We present examples of solutions implemented by the studied intermediaries. We conclude by discussing the theoretical and empirical perspectives introduced by this work.

\section{Literature review: Highlighting core functions of Innovation Intermediaries}

Previous studies have distinguished different roles and functions of innovation intermediaries (e.g., Howells, 2006). Beyond connecting actors, this literature highlight that intermediaries fulfil a range of specific functions to foster collective innovation. Drawing on earlier contributions, each touching on different aspects of the intermediary role (e.g. Klerkx \& Leeuwis, 2009; Nambisan et al., 2012; Fawcett et al., 2012; van Lente et al., 2003), we have identified four core functions that appear to be fulfilled by all types of intermediaries in the context of innovation: (i) connecting actors; (ii) involving, committing, and mobilising actors; (iii) solving, avoiding, or mitigating potential conflicts of interests; and (iv) (actively) stimulating the innovation process and innovation outcomes.

Different types of innovation intermediaries have been analysed and described in previous studies. Three distinct types of intermediaries that occur in different settings can be distinguished: (1) intermediaries for problem solving, (2) intermediaries for technology transfer, and (3) intermediaries as coordinators of networks in innovation systems. This categorisation might not be exhaustive, but it highlights the fact that whatever the mission of innovation intermediaries, and although they may face different problems or challenges, they all fulfil the four core functions listed above.

\subsection{Intermediaries for Problem Solving}

The intermediary "broker for problem solving" comes into play when a company lacks knowledge or skilled resources for solving a specific problem or for developing innovative new ideas. The intermediary offers access to external knowledge by either establishing 
bridges to external experts (e.g., in the case of marketplaces) or contributing knowledge from their own experiences (e.g., in consulting activities).

There are many actors that play the same role as brokers for problem solving, such as the following: consultants (Bessant \& Rush, 1995), knowledge-intensive business services or KIBS (Klerkx \& Leeuwis 2008, 2009), knowledge brokers (Hargadon, 1998; Hargadon \& Sutton, 1997), innovation marketplaces (Lichtenthaler \& Ernst, 2008) and idea scouts or technology scouts (Nambisan \& Sawhney, 2007). Previous studies on intermediation described actors such as Evergreen IP (Nambisan \& Sawhney, 2007), InnoCentive (Sieg et al., 2010; Surowiecki, 2004; Diener \& Piller, 2010), NineSigma, Yet2.com, and IDEO (Hargadon, 1998).

In this configuration, the primary function of the intermediary is clearly to connect seeking companies with problem solvers. However, the literature also describes other important functions, which are fulfilled either primarily by the intermediaries or in coordination with the client companies:

- Not only potential solvers but also problem seekers should be mobilised. Hence, there is a need to "enlist scientists" (Sieg et al., 2010, p. 285) who are not used to submitting their problems to external parties.

- Knowledge transactions require both that problems be articulated to external actors and that the "problem recipients" be able to make sense of the defined problem. As Sieg et al. (2010) have shown, the client company must carefully select the right problem and thereby manage the conflict (or trade-off) between seeking the "Holy Grail" solution and offering solvable tasks to externals experts. Selecting problems at early stages in the innovation process has been found to be favourable because the solution space is still sufficiently large and internal scientists have not yet become dulled to complexity issues and technical jargon.

- Finally, the intermediary will fulfil its role only if innovative solutions can be found, which often requires the stimulation of special learning processes. It has been demonstrated that the role of the intermediary is not only to scan and transfer information but also to organise the articulation, combination and manipulation of knowledge (Bessant \& Rush 1995). Thus, this type of intermediary is also concerned with building its own innovation capabilities (Howells, 2006, Klerkx \& Leeuwis, 2008). 
The manner in which problems are decomposed and formulated is recognised as a critical success factor for innovation brokers.

The four above-described core functions of this type of intermediary are summarised in the following table:

Table 1. Core functions of an intermediary as a broker for problem solving

\begin{tabular}{ll}
\hline Core Functions & Examples \\
\hline Connect & $\begin{array}{l}\text { Connect seeking companies with problem solvers (e.g., } \\
\text { Nambisan \& Sawhney, 2007) }\end{array}$ \\
\hline Involve / commit / mobilise & $\begin{array}{l}\text { Enlist scientists by defining common rules supported by } \\
\text { internal "champions" (Sieg et al., 2010) }\end{array}$ \\
\hline Solve / avoid conflict & $\begin{array}{l}\text { Define the right problem; avoid conflict between exceedingly } \\
\text { high expectations ("Holy Grail") and limited solution } \\
\text { capacities (Sieg et al., 2010) }\end{array}$ \\
\hline Stimulate innovation & $\begin{array}{l}\text { Articulate and combine knowledge (Bessant \& Rush, 1995), } \\
\text { re-engineer knowledge (Klerkx \& Leeuwis, 2008) }\end{array}$ \\
\hline
\end{tabular}

\subsection{Broker for Technology Transfer}

This type of intermediation is required when new technologies have been invented and developed but the inventor cannot commercialise them internally either because of a lack of resources, lack of business or market knowledge or noncompliance with the prevailing business model and/or business strategy. In such situations, intermediaries offer support in bringing the technology to the market by providing access to potential users of the technology using sufficient resources, legal and IP knowledge, or venture capital opportunities, for instance.

We find various labels in the literature for a second configuration, such as technology brokers or IP brokers, university technology transfer offices, liaison departments (Hoppe \& Ozdenoren, 2005), technology-to-business centres, out-licensing agencies (Shohet \& Prevezer, 1996), business incubators (Pollard, 2006; Nambisan \& Sawhney, 2007), and venture capitalists (Nambisan \& Sawhney, 2007). All of these actors are recognised to facilitate the transfer of knowledge or technology across firm or sector boundaries. 
Intermediaries such as Ignite IP (Nambisan \& Sawhney, 2007), Forthright Innovation and the Lanarkshire Business Incubator Centre (Pollard, 2006), and the Siemens Technology-toBusiness Centre and Technology Accelerator units (Gassmann \& Becker, 2006) have been studied with regard to the intermediary's role as broker for technology transfer.

The primary function of the intermediary is to organise new connections between distant academic- or industry-based science and industry players in search of new opportunities (Turpin et al., 1996). However, the role of this intermediary is not limited to liaison services:

- Technology providers and potential users must be convinced and mobilised. To function properly, the intermediary must engage in various marketing activities, and must make the technologies visible to potential investors (Thursby et al., 2001).

- Special attention should be paid to potential conflicts of interests. The intermediary is positioned between the inventor (or research unit) and the companies interested in the new technology. Therefore, the intermediary must consider the interests of inventors, which are often not limited to financial aspects (e.g., academic publications, honour and reputation, or competition aspects), as well as the interests of financial investors who seek to gain as much knowledge of the technology and its profitability prospects as possible before the actual transaction occurs (Shohet \& Prevezer, 1996).

- Finally, new uses of the technology must be explored to value the technological potential existing beyond the evident and trivial applications. Here, the intermediary often becomes deeply involved from a technical perspective as well, supporting the identification of potential technology applications and providing assistance in structuring and "moving" the knowledge from the inventor to the investor (Becker \& Gassmann, 2006).

Hence, the four core functions of this type of intermediary can be summarised as follows:

Table 2. Core functions of an intermediary as a broker for technology transfer

\begin{tabular}{ll}
\hline Core Functions & Examples \\
\hline Connect & $\begin{array}{l}\text { Establish connections between academic or industry science } \\
\text { and external players in the market (Turpin et al., 1996) }\end{array}$ \\
\hline Involve / commit / mobilise & $\begin{array}{l}\text { Perform marketing activities to attract potential investors } \\
\text { (Thursby et al., 2001) }\end{array}$ \\
\hline
\end{tabular}


Balance heterogeneous (conflicting) stakeholder interests, Solve / avoid conflict particularly financial and non-financial objectives (Shohet \& Prevezer, 1996)

Stimulate innovation

Actively engage in the exploration of new technology uses and the transfer of knowledge (Becker \& Gassmann, 2006)

\subsection{Networker or Bridger in Innovation Ecosystems}

The literature has described a third type of configuration in which intermediaries facilitate dynamic collaboration in innovation projects on a larger scale and for longer time horizons. We speak of "innovation systems" intermediation (Inkinen \& Suorsa, 2010) when considering innovation not from a company perspective, but rather, on a macro-economic level for geographical or industrial clusters (which may even include entire nations and their governments). Collaboration in such innovation systems is encouraged by not only technology policies but also dedicated organisations operating at the core of the innovation system. We find various occurrences of this type of intermediaries: science/technology parks (Löfsten \& Lindelöf, 2002), geographical innovation clusters (McEvily \& Zaheer, 1999), regional technology centres, technical committees, task forces, standards bodies (van Lente et al., 2003), and "brokers in innovation networks" (Winch \& Courtney, 2007).

These intermediaries support networking and bridging amongst a multitude of actors within a certain industry or within a geographical cluster. They create common visions, define common objectives, invite new participants, and provide all types of support. In this last configuration, the function of the intermediary is still to connect people and organisations. However, the connection is all the more complicated because the relevant stakeholders are not always identified ex ante and successful intermediation requires ongoing multilateral exchange to be adopted within the network, in opposition to the singular mission-complete ("problem solved" or "technology transferred") objectives in the first two intermediary configurations. Intermediaries must initiate linkages and facilitate accessibility to resources and knowledge. This process includes building infrastructures, sustaining networks, and facilitating exchange between the actors (van Lente et al., 2003).

Here again, other functions are equally important: 
- Technology providers and potential users must be convinced and mobilised. Convincing is a matter of framing a common issue that is considered a problem by potential actors in the innovation system. Sufficient exogenous incentives (e.g., market growth potential and economic factors) are required but can be complemented by resource mobilisation activities (e.g., competence and human capital, financial capital, and complementary assets) provided or organised by the innovation intermediary (Bergek et al., 2008).

- The need for collaboration clearly implies a necessity to avoid sources of conflicts. The introduction of new technologies often implies a need for change, to which established market actors resist. The intermediary can facilitate the formation of an "advocacy coalition", which places new objectives on the agenda and creates "legitimacy for a new technological trajectory" (Hekkert et al., 2007, p. 425). For instance, in the case of environmental care, the opposing interests of different actors and resulting conflicts could not be resolved without the intervention of a legitimised intermediary.

- Finally, the role of the intermediary is to stimulate innovative approaches. According to van Lente et al. (2003, p. 256), the intermediary supports the "learning processes, by enhancing feedback mechanism and by stimulating experiments and mutual adaptations". More generally, the challenge is to develop and offer favourable conditions for learning and experimenting, i.e., to create a place for collective innovation.

The four core functions of this type of intermediary can be summarised as follows:

Table 3. Core functions of an intermediary as an ecosystem bridger

\begin{tabular}{ll}
\hline Core Functions & Examples \\
\hline Connect & $\begin{array}{l}\text { Create and maintain a network for ongoing multilateral } \\
\text { exchange (van Lente et al., 2003) }\end{array}$ \\
\hline Involve / commit / mobilise & $\begin{array}{l}\text { Mobilise resources: Human capital, financial capital, and } \\
\text { complementary assets (Bergek et al., 2008) }\end{array}$ \\
\hline Solve / avoid conflict & $\begin{array}{l}\text { Create legitimacy for a new technological trajectory, create a } \\
\text { common agenda for actors with different (opposing) interests } \\
\text { (Hekkert et al., 2007) }\end{array}$ \\
\hline Stimulate innovation & $\begin{array}{l}\text { Support learning processes, foster feedback, stimulate } \\
\text { experiments and mutual adaptations (van Lente et al., 2003) }\end{array}$ \\
\hline
\end{tabular}




\subsection{Core Functions of innovation intermediation: synthesis}

Drawing on the literature, we identified four core functions that appear to be fulfilled by various types of intermediaries in the context of innovation: (i) connecting actors; (ii) involving, committing, and mobilising actors; (iii) solving, avoiding, or mitigating potential conflicts of interests; and (iv) (actively) stimulating the innovation process and innovation outcomes. We show that, according to the literature, distinct types of innovation intermediaries fulfil these four core functions.

Yet, previous studies do not account for how the degree of unknown may modify the nature of the different functions for the three types of intermediaries. This leads to difficulties to acknowledge the complex role and actions of intermediaries in some specific cases. For all types and functions, intermediaries come into play and offer their services when situations are rather well defined. But they can also face high degree of unknown, which may raise new managerial challenges and may impact how they can fulfil the previously discussed functions. In the following, we investigate the nature of innovation intermediation when the degree of unknown is high.

\section{Exploring the Challenges of the Intermediation in the Unknown}

In situations of low degree of unknown, actors in collaborative innovation endeavours are attracted by a clear common goal, which an intermediary can express and communicate. Similarly, conflicting stakeholders can work together because the necessity and expectations are sufficiently high for all and the role of the innovation intermediary is therefore to support the collaboration. Indeed, in intermediation in low level of unknown, intermediaries are characterised by different degrees of uncertainty. The coordination failure of a pure market solution creates the need for intermediaries, calling for coordinative action at different levels of uncertainty. Intermediaries handle the market failure in different ways. With brokers for problem solving, those in need of knowledge are aided in finding those that possess it. With knowledge transfer intermediaries, knowledge holders must find problems that can be solved with their knowledge. There is hence a low degree of information obscurity; problems and their solutions can be understood by the key actors. In bridging situations within an innovation ecosystem, an actor with a higher need for innovation combines different sources of knowledge to create the plan for creating solutions. In all circumstances, there exists both a 
type of goal, problem or vision and uncertainty regarding different possibilities to resolve the issue at hand.

However, what if there is no common goal or common vision, and the field of innovation seems very blurry? What if the intermediary alone cannot identify a common goal or common problem? What if there is no legitimate place to which an intermediary can invite potential stakeholders to begin to work together to create a common goal? In some situations, knowledge that is needed, technologies that should be developed and relevant stakeholders are not known in advance. Rather, they will be outputs or intermediate results of the exploration of the unknown. We characterize such situations as of high degree of unknown, and the role of intermediaries can actually be to participate in those innovation processes where the degree of the unknown is high.

By "unknown", it is simply meant the absence of knowledge in a situation of collective action. Many works have dealt with the notion of "unknown" in management. We acknowledge that different lines of research have chosen to use different terms. For example, in knowledge management, a common phrase used to describe the unknown is "opaque" or the degree of "opacity". In chaos research and finance, authors refer to "ambiguity". In this paper, we choose the term "unknown" to stress the importance of design in innovation processes (although it is arguably very close to "opacity" and "ambiguity").

Recent advances in design theory and management research have helped to clarify the richness of the notion of the unknown. Historically the notion was used in management to try to characterize what is beyond the limits of rational choice, and requires a design effort. In a first approach, dealing with the unknown was assimilated to (complex) problem solving (Simon 1969, Hevner et al. 2004), relying on complexity elimination (by modularization, independence creation,...) or ignorance (by dealing with simpler and higher level aggregates), in particular in system engineering. It has then been shown, on the one hand, that dealing with the unknown could not be reduced to managing complex problems (Rittel 1972, Schön 1990, von Foerster 1991, Hatchuel 2002, Dorst 2006) and should be extended to deal with "figural complexity" and "details" (Schön 1990), with wicked problems (Rittel 1972), with "desirable unknowns" (Hatchuel 2002), etc. On the other hand it has also been shown that dealing with the unknown should be distinguished from dealing with uncertainty (Knight 1921, Loch et al. 2006). According to Knight (1921) uncertainty refers to events whose probabilities cannot be 
determined. For instance, the probability that it will snow in summer is very low - we know what snowing means, but this event is unlikely to occur in summer. In contrast, forms of life existing on exoplanets are unknown in the sense that it is difficult to conceive the large variety of forms they can take, because the nature of this life it-self is unknown. One should distinguish between not knowing about the occurrence of future events (uncertainty) and not knowing about the nature of these events (unknown). More generally, the distinctions between complexity, uncertainty and unknown have been developed and grounded in design theories (Hatchuel \& Weil, 2009; Le Masson \& Weil, 2013). The authors have shown that managing the unknown should integrate design capacities in collective action, i.e. the capacities to create new dimensions, new design parameters as well as new values and new design spaces for action (eg. Schön 1990, Grin 2005, Dorst 2006, Hatchuel et al. 2010). In particular, innovation processes are precisely about addressing the unknown: indeed, developing a new object means that this object was previously unknown and that the unknown was then explored.

Building upon this definition of "unknown", we investigate the role intermediaries can play if the objects, actors, vision/goals and legitimacy of context do not exist, are partially "unknown" and need to be designed. Table 4 lists the challenges that may be faced with reference to the core functions of intermediaries.

Table 4. Challenges raised in situations of high degree of the unknown

Core Functions

Connect Can intermediaries connect parties when relevant stakeholders are not identified?

Involve / commit / mobilise Can intermediaries mobilise without a positive reputation or a legitimate proposition?

Avoid / resolve conflicts Can intermediaries overcome conflict without pre-existing common interests?

Stimulate innovation Can intermediaries stimulate innovation without pre-defined problems or research questions?

In the following part of the paper, we analyse four empirical cases in which innovation intermediaries faced a relatively high degree of unknown, and each of them had to address some of the questions raised in Table 4. We analyse the solutions developed in each case to investigate how the managerial challenges were met. 


\section{$4 \quad$ Research Methodology}

\subsection{Case-Study Approach, Data Collection, and Data Analysis}

Given the lack of prior research on the role of innovation intermediaries in situations of high degree of unknown and our interest in studying corresponding intermediaries within their organizational contexts, we chose considered a qualitative case-study approach (Yin 2014). The case-study approach is particularly suitable for studying "how" research questions, and allowed us to explore the managerial challenges of the unknown in their real-life contexts as well as to conduct an in-depth investigation of how innovation intermediaries resolve these challenges. To identify a set of relevant managerial principles, it was also important to examine multiple cases since we could not expect all pre-identified challenges to be equally relevant to a single case. In other words, most likely, a single case would not have been exhaustive when analysing all four main intermediary functions as well as the challenges associated with these functions under conditions of high degree of unknown.

The rationale for selecting the case sites followed an information-oriented selection strategy (Flyvbjerg 2006). This strategy aims to maximize the utility of information from case studies by selecting cases "on the basis of expectations about their information content" (ibid., p. 230). On this basis, we selected the cases of four innovation intermediaries in Germany, Sweden, and France for inclusion in our study (see Table 5). In each of these four cases, the degree of unknown was high, and at least one of the above-described managerial challenges (see Table 4) was particularly pronounced. Although the specific challenges of the selected cases were rather heterogeneous (see section 4.2 below), the cases exhibited considerable similarities in terms of the main functions fulfilled by each intermediary. Ultimately, this allowed us to consolidate the individual case insights into a set of managerial principles for intermediation in the unknown.

Table 5. Case overview and data sources

\begin{tabular}{lllll}
\hline & Siemens & SAFER & CEA-CEBC & I-Care \\
\hline Country & Germany & Sweden & France & France \\
\hline Time of & January 2011 & September 2008 & March 2010 & September 2009 \\
analysis & October 2011 & -December 2012 & April 2013 & - August 2011 \\
\hline Interviews and & 6 interviews & $>$ 55 interviews & 41 interviews & 21 interviews \\
\hline
\end{tabular}




\begin{tabular}{|c|c|c|c|c|}
\hline workshops & $\begin{array}{l}\text { with business } \\
\text { unit managers } \\
\text { and intermediary } \\
\text { representatives }\end{array}$ & $\begin{array}{l}\text { with } \\
\text { intermediary } \\
\text { representatives } \\
\text { and partner firm } \\
\text { representatives } \\
>5 \text { research } \\
\text { workshops }\end{array}$ & $\begin{array}{l}\text { with } \\
\text { intermediary } \\
\text { representatives } \\
\text { and stakeholders } \\
1 \text { collective } \\
\text { design workshop }\end{array}$ & $\begin{array}{l}\text { with } \\
\text { stakeholders } \\
2 \text { research } \\
\text { workshops }\end{array}$ \\
\hline $\begin{array}{l}\text { Interview } \\
\text { durations }\end{array}$ & $\begin{array}{l}40 \text { minutes to } \\
1.5 \text { hours }\end{array}$ & $\begin{array}{l}45 \text { minutes to } 2 \\
\text { hours }\end{array}$ & 1.5 to 2 hours & 1.5 to 2 hours \\
\hline $\begin{array}{l}\text { Supplementary } \\
\text { data }\end{array}$ & $\begin{array}{l}\text { Internal } \\
\text { documents, } \\
\text { Onsite } \\
\text { observations }\end{array}$ & $\begin{array}{l}\text { Participation in } \\
\text { meetings and } \\
\text { workshops, } \\
\text { Quantitative } \\
\text { surveys }\end{array}$ & $\begin{array}{l}\text { Participation in } \\
10 \text { project } \\
\text { meetings }\end{array}$ & $\begin{array}{l}\text { Analysis of } \\
\text { European- } \\
\text { funded projects, } \\
\text { Participation in } \\
2 \text { workshops }\end{array}$ \\
\hline
\end{tabular}

To collect data, we conducted a total of over 120 semi-structured interviews with intermediary representatives and other stakeholders. The interviews lasted between 40 minutes and 2 hours (see Table 5 above). All interviews were tape-recorded and transcribed. Follow-up emails and phone calls were used to clarify any questions that arose during the interview transcription and data analysis. To triangulate the interview data, we also ran research workshops with participants from the involved organizations, attended internal meetings and workshops, carried out quantitative surveys, visited the case sites on a regular basis to make direct observations, and collected internal documents such as presentations, reports, and meeting minutes. The collection of data from multiple sources is consistent with established guidelines on case-study research (e.g., Eisenhardt 1989; Yin 2009). Most importantly, this data triangulation allowed us to do pattern matching across data sources, and helped us identify convergent lines of inquiry.

Before analysing the case data, we integrated all interview transcripts, field notes, and other relevant documents into a case study database (Yin 2009). We then coded the collected data on a case-by-case basis with a particular focus on the four managerial challenges related to a high degree of unknown (see Table 4), and compiled short summaries for each case including preliminary case findings and interpretations. The case summaries also facilitated cross-case comparisons, which require a more macro view of each case (cf. Choudhury and Sabherwal 2003). While the analytical process was necessarily interpretive, we tried to minimize the involved subjectivity by iteratively moving back and forth between the case data and the case summaries during the analysis. Furthermore, to facilitate the analysis process, all members of 
the research team met several times in person to present, discuss, and compare the case findings, to identify patterns, as well as to draw conclusions about the managerial principles that innovation intermediaries apply to address the challenges of the unknown.

Next, we explain the background, the actors, and the role of the intermediary for each case. Thereafter, in section 5, we focus on the contingency variable (degree of unknown), highlight the major challenge of the unknown for each case, and show how the intermediaries responded to these challenges in order to enable successful collective innovation.

\subsection{Presentation of the four case studies}

\subsubsection{The Siemens open innovation unit}

Siemens is one of few multinational corporations that have managed to run a successful business for more than 100 years. Such consistency cannot be explained by only operational excellence; effective R\&D processes are also required for the frequent development of marketable new products (and services). Although internal R\&D has been highly important ever since the company's foundation, collaborative R\&D occurring across business units and industrial sectors and used along the value chain with suppliers, customers and external communities is also part of innovation strategy. Nevertheless, some years ago, it became clear that new web-based technologies and developments in social behaviours (e.g., user cocreation, social networking, and online collaboration) called for a systematic approach to open innovation. For this purpose, a dedicated "Open Innovation" (OI) unit was installed at Siemens headquarters. The OI unit develops processes, tools, and governance mechanisms to complement other prevalent forms of (open) collaborative innovation. The OI unit supports three focus areas:

- Collaborative idea generation, particularly via internal and external idea contests: The OI unit supports the operative business units by defining idea contest topics and formulating challenges. The OI unit also provides access to supporting technology and maintains relationships with IT service providers. The unit also supports the process as a whole, from initiation to idea selection and subsequent follow-up activities.

- Collaboration with knowledge brokers (e.g., NineSigma, InnoCentive): The OI unit first internally promotes the opportunity to collaborate with knowledge and also aids in the formulation of the problem. The OI unit then fulfils a gate-keeping and quality assurance function in such collaborations with knowledge brokers. 
- Connecting Siemens experts around the world: The OI unit has implemented a new collaboration infrastructure, a network for experts from Siemens's various divisions and business units. This infrastructure allows internal technical experts around the world to share knowledge and ask for support. Collaboration is not limited to the primary technical area of expertise, as the head of the OI unit noted: Employees also engage in many other forums to offer and find "out-of-the-box" solutions to specific technical problems.

The OI unit can be viewed as an internal innovation intermediary for various sectors and business units. Specifically, this intermediary is an entity within a large enterprise.

\subsubsection{The collaborative arena SAFER}

Southwest Sweden is home to several major automotive companies, such as AB Volvo, Volvo Car Corporation, and Autoliv. It is in the interest of the different actors to collectively conduct research on vehicle and traffic safety to strengthen the automotive cluster. SAFER is organised to facilitate this work and provide a platform for innovation, as it acts as a host to a range of collaborative projects. The arena offers office facilities, meeting rooms, seminars, conferences, etc. to individuals at their institutional partners - companies such as AB Volvo, Autoliv, government agencies such as the Swedish Transport Administration, smaller technical consultancy companies, and universities such as Chalmers, the Royal Institute of Technology (KTH) and Gothenburg University. SAFER is an association consisting almost solely of its partners. The association is governed by an annual meeting of the partners and an elected board and led by a director who, with a few assistants, is responsible for maintaining daily operations. SAFER does not have judicial status in the regular sense (for practical reasons, the economic administration is managed via Chalmers). Without the partners, there would be no organisation. Approximately 170 people had access to the SAFER offices at the time of study.

SAFER hosts an array of projects - from pre-studies to large-scale testing projects to method development; however, they are all focused on the initial non-competitive phase of the innovation process. The collaborating partners pitch ideas on new projects to the other partners to find collaborators. On some occasions, collaborators are found outside of the boundaries of SAFER, where the extensive network of SAFER can be of use. SAFER thus provides a space for matchmaking and networking and offers a neutral and legitimate place in which those working on the projects can meet and work. 


\subsubsection{The agricultural cooperative CEA and the research centre CEBC}

The domain of agriculture must cope with serious innovation challenges to attain environmental sustainability. These challenges are present particularly in cereal plains, where intensive farming practices significantly damage biodiversity, as well as water and soil resources. This case study depicts a pioneer situation in the West of France in which a small agricultural cooperative, CEA (Cooperative Entente Agricole - 400 farmer members), has established a partnership with a research centre in ecology, the CEBC (Centre d'Etudes Biologiques de Chizé), to design solutions that reconcile agriculture and environmental protection on a landscape scale. Such collaboration is crucial to the exploration of innovative solutions, but it is challenging, as stakeholders have very different interests and are often in conflict. Through this initiative, CEA and the CEBC seek to play the role of an innovation intermediary, bringing together a plurality of stakeholders to design innovative farming and land management practices.

As an initial step in the project, the cooperative and the research centre organised a collective design workshop in May 2011. Most participants were cooperative farmer members and technicians, but other stakeholders such as local authorities were invited as well. Thirty people participated. Following this workshop, the cooperative and the research centre began a research-action project involving agronomy and ecology scientists, as well as farmers. This project will continue for four years and is co-funded by CEA, the CEBC and local authorities. The project aims to provide knowledge on environmentally friendly farming practices and governance challenges raised by agro-ecological projects that require coordination between heterogeneous stakeholders. This bottom-up initiative is thus now supported by public authorities.

\subsubsection{The I-Care cluster}

The I-Care cluster, launched in 2009 , aims to encourage collaborative projects involving industry and research laboratories in the Rhône-Alpes region (France) in the field of health technologies. One area in particular has attracted investment and R\&D efforts without producing significant results in terms of innovativeness: the need to improve the well-being of elderly people who face a loss of autonomy.

In France, the average age of the population is increasing; therefore, innovations using information and communication technologies (ICT) to assist people experiencing a loss of 
autonomy are highly sought after. However, the quality of proposed innovations has not met expectations. The I-Care cluster acted as an intermediary to explore new ideas collectively with the totality of stakeholders at several creativity workshops (60 participants). This intermediary influenced the nature of the interactions among these stakeholders by making paths of innovation that remain unexplored visible. To do so, the cluster developed a methodology based on a C-K theory framework (Hatchuel et al., 2011), which allowed for the unveiling and evaluation of paths of innovation that provided potential new ways of tackling the issue of autonomy. The methodology provided a means to objectify the distance between expectations in terms of innovation regarding a specific milieu and what the actual innovation capabilities of the sector could provide. The methodology was also a means to stimulate new concepts to be explored by the various actors in the sector.

\subsubsection{The four actors as intermediaries}

We can summarise our four cases with regard to the different functions of intermediaries: The following table indicates how the intermediaries in each case fulfilled these functions.

Table 6. Summary of the four case studies: Challenges in the unknown

\begin{tabular}{|c|c|c|c|c|}
\hline $\begin{array}{l}\text { Core } \\
\text { functions }\end{array}$ & Siemens & SAFER & CEA-CEBC & I-Care \\
\hline Connect & $\begin{array}{l}\text { Connect people } \\
\text { beyond local } \\
\text { (physical) } \\
\text { boundaries, } \\
\text { particularly by } \\
\text { introducing new } \\
\text { (web-based) } \\
\text { collaboration } \\
\text { platforms }\end{array}$ & $\begin{array}{l}\text { Connect } \\
\text { researchers and } \\
\text { specialists in the } \\
\text { vehicle and traffic } \\
\text { safety field } \\
\text { originating from } \\
\text { partners who } \\
\text { compete in the } \\
\text { market }\end{array}$ & $\begin{array}{l}\text { Connect } \\
\text { agricultural } \\
\text { professionals and } \\
\text { naturalists } \\
\text { (initially in } \\
\text { conflict) }\end{array}$ & $\begin{array}{l}\text { Connect } \\
\text { companies, health } \\
\text { organisations, } \\
\text { research } \\
\text { organisations, and } \\
\text { specialists (for } \\
\text { instance, } \\
\text { geriatricians) }\end{array}$ \\
\hline $\begin{array}{l}\text { Involve / } \\
\text { commit / } \\
\text { mobilise }\end{array}$ & $\begin{array}{l}\text { Promote methods } \\
\text { and tools across } \\
\text { sectors \& } \\
\text { business units and } \\
\text { allow employees } \\
\text { to present their } \\
\text { ideas to top } \\
\text { management }\end{array}$ & $\begin{array}{l}\text { Create a } \\
\text { legitimate place } \\
\text { for meeting and } \\
\text { innovating } \\
\text { (offices and lab } \\
\text { environments). } \\
\text { Collaborative } \\
\text { activities for idea } \\
\text { generation and } \\
\text { knowledge } \\
\text { sharing }\end{array}$ & $\begin{array}{l}\text { Organise } \\
\text { meetings and a } \\
\text { collective design } \\
\text { workshops: } \\
\text { introduce issues, } \\
\text { create mutual } \\
\text { understanding, } \\
\text { and formulate a } \\
\text { common goal }\end{array}$ & $\begin{array}{l}\text { Support the } \\
\text { various actors by } \\
\text { organising joint } \\
\text { creativity } \\
\text { workshops and } \\
\text { applying new } \\
\text { creativity } \\
\text { techniques }\end{array}$ \\
\hline Solve / & Create legitimacy & Written rules of & Collectively & Open discussion \\
\hline
\end{tabular}




\begin{tabular}{|c|c|c|c|c|}
\hline $\begin{array}{l}\text { avoid } \\
\text { conflicts of } \\
\text { interest }\end{array}$ & $\begin{array}{l}\text { for employee } \\
\text { participation by } \\
\text { engaging top } \\
\text { management in } \\
\text { official support of } \\
\text { the activities }\end{array}$ & $\begin{array}{l}\text { knowledge } \\
\text { sharing, but in } \\
\text { reality, } \\
\text { continuous } \\
\text { weighing off of } \\
\text { how much } \\
\text { information that } \\
\text { can be disclosed } \\
\text { to enable } \\
\text { productive work }\end{array}$ & $\begin{array}{l}\text { explore possible } \\
\text { solutions, make } \\
\text { interdependences } \\
\text { between } \\
\text { stakeholders } \\
\text { visible, and } \\
\text { highlight } \\
\text { common values }\end{array}$ & $\begin{array}{l}\text { during workshops } \\
\text { on the potential } \\
\text { future of ICT for } \\
\text { autonomy }\end{array}$ \\
\hline $\begin{array}{l}\text { Stimulate } \\
\text { innovation }\end{array}$ & $\begin{array}{l}\text { Collect and share } \\
\text { success stories, } \\
\text { thereby } \\
\text { motivating } \\
\text { followers in the } \\
\text { organisation }\end{array}$ & $\begin{array}{l}\text { Search collective } \\
\text { funding, run } \\
\text { workshops, } \\
\text { exhibitions, } \\
\text { collaborative } \\
\text { space, investment } \\
\text { in simulator } \\
\text { equipment, } \\
\text { publicly display } \\
\text { success stories }\end{array}$ & $\begin{array}{l}\text { Launch a } \\
\text { research-action } \\
\text { project with the } \\
\text { various } \\
\text { stakeholders that } \\
\text { is co-funded by } \\
\text { local authorities }\end{array}$ & $\begin{array}{l}\text { Make visible new } \\
\text { paths of } \\
\text { innovation by } \\
\text { revealing and } \\
\text { stimulating } \\
\text { unthought-of } \\
\text { opportunities. }\end{array}$ \\
\hline
\end{tabular}

\section{Results : the managerial challenges of the unknown and insights into the ways intermediaries resolve them}

We have observed that the intermediaries in all four case studies were engaged in the core functions that we identified in the literature. However, we found that the intermediaries in each of our cases also faced rather unusual, or challenging, situations - situations that had not been reported in previous studies. We now focus on each of these situations, explaining the particular challenge in the context of the case at hand. We then illustrate how the intermediary in question coped with these challenges.

\subsection{Connecting actors that have previously not been identified: Siemens}

Siemens is one of the largest enterprises in the world, with more than 350000 employees operating in more than 190 countries. The business is very diverse and is structured into four sectors (industry, energy, healthcare, and infrastructure \& cities). Logically, without smart ICT technologies, there would be little collaboration and exchange across business units. The phrase "If Siemens only knew what Siemens knows" (head of the OI unit) effectively indicates that there exists a vast body of knowledge that is naturally difficult to access outside local departments. 
Every day, many people in Siemens encounter challenging technical problems that must be resolved. In the past, problem solving was limited to individual specialists and local teams (engineers could ask colleagues on their teams). Perhaps in some cases, engineers personally knew experts outside their team. However, it was not possible to receive ideas and solutions from "unknown" colleagues.

One of the activities initiated by the OI unit was the development and implementation of an interactive online expert network within the Siemens intranet. This network is an infrastructure rather than a real network in a stricter sense because the nodes (Siemens employees) are not active participants on a permanent basis. Rather, the infrastructure enables employees across industrial sectors and various regions to build "ad-hoc" networks for specific problem solving challenges. Experts who operate in totally different industries can provide pieces of knowledge regarding problems that have been posted on this platform. As an example, one engineer in the Diagnostics unit was facing a problem and submitted it on the platform. Within 40 minutes, he received the first answer and, within 2 days, could collect 25 answers from experts around the world whom he neither knew personally nor had previously identified and selected as potential problem solvers for this ad-hoc network.

\subsection{Mobilising joint innovation while in competition: $S A F E R$}

The overall objective of the SAFER collaboration is to increase the competitiveness of the automotive cluster in southwest Sweden and act as an open innovation arena. The partners in SAFER have been self-selected, but recently, more effort has been devoted to the identification and attraction of new types of partners. Most of them have worked together before in different constellations. The larger organisations, such as Autoliv and Volvo, have several points of contact with SAFER: Several individuals collaborate in different areas of expertise. This strategy indicates that although the partner organisations are established, the stakeholders within those organisations that are relevant for different projects are not. There is an ongoing matchmaking process in the different organisations to put the relevant people to work together. Trust is created between individuals who act as contact points between the organisations, and this often involves the sharing of information that extends beyond what is actually allowed judicially (IP). Because of the specialisations of the different partners, they complement each other in terms of competences, thereby creating a new, shared form of organisation in the space between the partner organisations. 
Several of the partner organisations would engage in bilateral collaboration even if SAFER did not exist. However, SAFER becomes a "safe haven", a legitimate place for collaboration in ways that otherwise would not have been possible because of competition law, market positioning, political conflict or lack of initiative. Most of the individuals involved agree that the existence of a physical space in which to meet, create trust, drive projects, and thereby collectively share knowledge and develop new ideas is absolutely central to the success of SAFER. SAFER is neither a traditional university competence centre nor a private research institute. Instead, SAFER is an arena for collaboration that is "self-regulated", as its partners work together in different forms to collectively pool resources, skills and capabilities to succeed in the safe area. If one of the other partners would host the collaboration, it would not be regarded as equally free. However, it is only the quality of the work conducted in the name of SAFER that legitimises its existence.

\subsection{Resolving conflicts without pre-existing common interests: CEA-CEBC}

Farmed ecosystems' stakeholders generally have contradicting interests regarding their resources; nevertheless, the actions initiated by some actors have impacts on others. As a consequence, conflicts regarding situations are common, particularly between farmers and naturalists or other citizens. The challenge of addressing potential conflicts of interests is thus essential to overcoming such a situation and initiating a collective innovation process to reconcile agricultural protection and environmental preservation.

In the case studied, the ecologists proposed the development of grasslands in the cereal plain. Ecologists consider grasslands to regenerate regulations crucial for ecosystem functioning (water storage, insect reproduction...), as these areas are more "stable" than cereal crops. Indeed, grasslands are not ploughed every year and require fewer pesticides than cereal crops. However, cereal farmers initially did not view grasslands as an acceptable solution despite their ecological interests, as they were not sufficiently profitable: a market for fodder hardly exists.

To overcome the grassland reintroduction conflict, the "grassland" proposition was not considered a turnkey solution with a predefined value for which a consensus had to be reached. Rather, the proposition was considered the departure point of a design process involving a large range of agro-ecosystem stakeholders (Berthet et al., 2012). CEA and the CEBC organised a workshop to initiate a collective design process, departing from the initial 
proposition "designing grasslands for a sustainable agro-ecosystem". The aim was to cause the stakeholders to revise the identity of grasslands (not only an ecological habitat; not only an area for intensive fodder production) and together explore the potential values of "new kinds of grasslands".

The stakeholders first shared knowledge of grasslands and then explored possible new functions, such as the regeneration of insect populations and higher biodiversity throughout the plain. Indeed, grasslands represent biodiversity sources in a highly disturbed ecosystem. The exploration, led by stakeholders, made visible interdependences between them: they found that providing such ecological functions required further coordination between farmers. For instance, managing grassland location throughout the landscape makes it possible to optimise insect dispersion. The design workshop also brought to light new opportunities for creating value, such as the production of high-quality dairy products with local forage from environmental-friendly grasslands or the improvement of water quality.

\subsection{Stimulating innovation by unveiling unexplored paths of innovation: I-Care}

In France (as in Europe), the average age of the population is increasing. The number of French citizens over 75 years of age will become 2.5 times higher between 2000 and 2040, reaching a total of 10 million people, and it is estimated that 1.2 million people will have lost their autonomy by 2040. Innovation using ICT to aid people experiencing a loss of autonomy is highly sought after to provide means for elderly people to enhance their quality of life and stay at home longer. The mainstream path with regard to autonomy addresses the monitoring of a person in his or her home using numerous various high-tech devices (e.g., a medallion that can trigger a remote alarm if necessary). These types of projects have been on the market for over 15 years already (and there are plenty of these projects); however, none of them have had commercial success. Thus, despite a well-expressed need, the innovativeness of the field appears to be stale.

The discussion initiated by the I-Care cluster with geriatricians led to the discovery of the concept of fragility. Fragility is described as an intermediate state between robustness and dependence. For example, during this period of life, for a large proportion of seniors, the risk of falling or developing a disease is greater. 
The problem of autonomy was then reformulated using this new concept. Shifting the focus from the concept of the use of ICT in increasing the autonomy of seniors to the concept of fragility revealed new interdependences among the actors, as well as new actors to involve, and facilitated understanding of the current staleness of these innovation processes.

Thus, the actions of the cluster and the proposed conceptual broadening facilitated the opening of the field to new stakeholders (e.g., in connection to fragility and the seniors' environment). Various actions performed by the cluster (e.g., a seminar emphasising the lack of knowledge, a workshop for working collaboratively on original concepts, and meetings with involved entities) led to the emergence of awareness of new possibilities and, therefore, to the appropriation of new alternative technologies by all of the ecosystem's stakeholders and engendered new modalities of interactions among these stakeholders.

\section{Discussion}

This set of cases led to original management principles for addressing each of the four forms of the unknown. These management principles are summarized in table 7 . These principles are derived from the variants of the core intermediary functions (connect, involve, resolve conflict, stimulate innovation) that the intermediaries in our cases deploy, which we first describe::

- Connect unknown people: Expert networks are well known in the literature - and very famous cases at Siemens have been already studied in depth (Voelpel et al., 2005). However, these networks connect already identified experts. Interestingly, in the current Siemens case, we make note of the capacity to build an "ad-hoc" network with regard to an issue that can be new to the firm. Although the implementation of expert networks in the general case is often based on technical skills and scientific disciplines, the building of the ad-hoc network in our case is driven by the innovation issue itself. The temporary "organisation" is initiated on demand and disassembled when the issue is resolved. The intermediary - in this case, via the technical platform rather than active involvement makes this method possible. The solution that the Siemens case provides extends beyond the classical "solver-solution", in which actors are supposed to provide one solution. The solution also extends the "networker" role, in which intermediaries connect parties in innovation ecosystems: In a sense, the entire Siemens organisation can be understood as 
an innovation ecosystem, but because of the very large number of employees, it is impossible to "know" all of the potential actors in advance. Thus, the actors are unknown. Finally, it should be emphasised that the building of ad-hoc networks is not based on incentives - motivation is intrinsically based on the innovation issue. Experts commit to the emerging network because of their interest in addressing the issue - which is a strong motivation, being perhaps even stronger than usual economic incentives (Pink, 2009; Glucksberg, 1962).

- Mobilise, interest, involve a legitimate place: SAFER was initiated because different market players shared a common interest - vehicle and transport safety. By creating SAFER, the stakeholders also created a legitimate place for collaborative research and innovation. In the case of SAFER, the stakeholders come together not to find "the solution", but rather, because of the favourable collaborative conditions, to invent solutions. SAFER demonstrates a striking case in which the intermediaries do not raise expectations regarding the solution (so-called anticipative expectations) but raise expectations regarding the capacity to generate multiple solutions (so-called generative expectations, cf. Le Masson et al., 2012). Legitimacy is based not on the output but on the working conditions. Note that this reasoning was already the logic of the machine shop culture at the root of Edison Invention Factory (Israel, 1998; Millard, 1990). Just as in Edison's factory, working at SAFER is more innovative and more fruitful in terms of innovation output than working inside one's own parent company.

- Conflicts as a resource for collective exploration: Contrary to "intermediation in the known", for which conflict avoidance or trade-offs is often the rule, the management principle illustrated by CEA-CEBC is to address conflict in a creative manner and even to address conflict to be creative. Indeed, conflicts reveal a need for innovation that would reconcile contradictory interests and, hence, might be a source of radical innovation. It is well known that innovation is also marked by power relationships (Santos \& Eisenhardt, 2009); however, the works on these topics have demonstrated that this power relationship is based precisely on the definition of boundaries. Conversely, the intermediation in the unknown consists of blurring existing boundaries by reinventing their definitions (new markets, new technological variants and combinations, new constraints understanding, questioning the identity of the object of conflict...), which creates opportunities for "new boundaries" that correspond to possible common interests. In the case of CEA and CEBC, at first, the actors had very distinct understandings of the key use of grassland: the idea that grassland is "for production" (boundary 1) vs. the idea that grassland is "for bird 
preservation" (boundary 2). The intermediation work consisted of creating new "grasslands" designs that could combine several values (productive farming, as well as the preservation of fauna and water resources). The intermediary redesigned the identity (functions and design parameters) of grasslands and hence created the conditions for overcoming conflicts and power relations.

- Sharing an agenda of open issues instead of sharing knowledge. The I-Care case illustrates a management principle for handling ill-defined problems. The absence of well-identified problems might hinder knowledge sharing. However, knowledge is not necessarily the key resource in radical innovation. It is established that creativity and the capacity to imagine can also produce innovations. Thinking out of the box is helpful in avoiding so-called fixations (Agogué et al., 2011; Hatchuel et al., 2011; Jansson \& Smith, 1991), so today, it is a critical capacity for radical innovation, a new form of absorptive capacity (Le Masson et al., 2012a, 2012b). Moreover, knowledge sharing is often critically linked to confidentiality or IP issues; sharing questions and unsolved problems is paradoxically easier.

Table 7. Management principles for intermediation in the unknown

\begin{tabular}{|c|c|c|c|}
\hline Core Functions & $\begin{array}{l}\text { Can intermediaries be } \\
\text { active in the } \\
\text { unknown? }\end{array}$ & $\begin{array}{l}\text { Management } \\
\text { principles }\end{array}$ & $\begin{array}{l}\text { Illustration with the } \\
\text { empirical cases }\end{array}$ \\
\hline Connect & $\begin{array}{l}\text { Can they connect } \\
\text { parties when relevant } \\
\text { stakeholders are not } \\
\text { identified? }\end{array}$ & $\begin{array}{l}\text { Develop a capacity } \\
\text { to create an ad-hoc } \\
\text { network in which } \\
\text { the right people } \\
\text { commit to } \\
\text { collective } \\
\text { innovation (not } \\
\text { incentives) }\end{array}$ & $\begin{array}{l}\text { Siemens developed } \\
\text { an interactive online } \\
\text { expert network } \\
\text { within its intranet. } \\
\text { This infrastructure } \\
\text { enables employees } \\
\text { across various } \\
\text { industrial sectors } \\
\text { and regions to build } \\
\text { "ad-hoc" networks } \\
\text { for specific problem } \\
\text { solving challenges. }\end{array}$ \\
\hline $\begin{array}{l}\text { Involve / commit / } \\
\text { mobilise }\end{array}$ & $\begin{array}{l}\text { Can they mobilise } \\
\text { joint innovation while } \\
\text { in conflict and } \\
\text { competition? }\end{array}$ & $\begin{array}{l}\text { Create a legitimate } \\
\text { place for collective } \\
\text { innovation (not a } \\
\text { shared vision) }\end{array}$ & $\begin{array}{l}\text { The SAFER } \\
\text { association offers to } \\
\text { its members a } \\
\text { neutral and } \\
\text { legitimate place in } \\
\text { which those } \\
\text { working on } \\
\text { collective }\end{array}$ \\
\hline
\end{tabular}




\begin{tabular}{|c|c|c|c|}
\hline & & & $\begin{array}{l}\text { innovation projects } \\
\text { can meet and work. }\end{array}$ \\
\hline $\begin{array}{l}\text { Avoid / resolve } \\
\text { conflicts }\end{array}$ & $\begin{array}{l}\text { Can they overcome } \\
\text { conflict without pre- } \\
\text { existing common } \\
\text { interests? }\end{array}$ & $\begin{array}{l}\text { Handle conflict in a } \\
\text { creative way to } \\
\text { leverage collective } \\
\text { exploration }\end{array}$ & $\begin{array}{l}\text { The CEA and the } \\
\text { CEBC initiated a } \\
\text { collective design } \\
\text { process of } \\
\text { grasslands to } \\
\text { overcome the initial } \\
\text { land use conflict } \\
\text { between farmers } \\
\text { and naturalists. }\end{array}$ \\
\hline $\begin{array}{l}\text { Stimulate } \\
\text { innovation }\end{array}$ & $\begin{array}{l}\text { Can they stimulate } \\
\text { innovation without } \\
\text { pre-defined problems } \\
\text { or research questions? }\end{array}$ & $\begin{array}{l}\text { Share an agenda of } \\
\text { open issues and } \\
\text { questions (before } \\
\text { sharing knowledge } \\
\text { and answers) }\end{array}$ & $\begin{array}{l}\text { I-care developed a } \\
\text { methodology based } \\
\text { on design theories } \\
\text { to assess existing } \\
\text { innovation paths } \\
\text { and to identify new } \\
\text { concepts to be } \\
\text { explored by the } \\
\text { innovation } \\
\text { ecosystem } \\
\text { addressing elderly } \\
\text { people's autonomy. }\end{array}$ \\
\hline
\end{tabular}

As for managerial implications, our study underlines the difficulties that innovation intermediaries as well as open innovation managers currently face. First of all, there is often ambiguity regarding the degree of unknown in innovation dynamics, and it is all the more so in open innovations. Indeed, recognizing that the issue at stake goes beyond the expertise of the stakeholders and requires a real exploration approach is not easy in it-self, as overconfidence in what is currently known sometimes prevent managers from realizing how much is actually unknown. And because of the organizational complexity that open innovation fosters, one risk of radical open innovation is to engage in the process as if it is already known in advance which knowledge that is needed, which technologies should be developed and which stakeholders that are relevant. Both innovation intermediaries and open innovation managers should first conduct a diagnosis of the level of unknown prior launching the open innovation dynamics. This diagnosis may also help clarify the outputs of the process. Indeed, in high level of unknown situations, the identification of both the knowledge to acquire and the stakeholders to involve should be outputs or at least intermediate results of the open innovation process. 


\section{Conclusion and Perspectives on studying Intermediation in the Unknown}

Our study contributes to the theory of innovation intermediaries by introducing the degree of unknown as a key contingency variable. We characterise a set of management principles for intermediaries in situations in which the degree of unknown is high. This set of principles is consistent with previously described intermediaries such as architects of the unknown and colleges of the unknown. Yet, our contribution goes beyond previous proposals by clarifying the notion of unknown in open innovation as well as the activities required for intermediation in the unknown.

One of the consequences of this work is the uncovering of the paradoxical complexity of this so-called intermediation. In early studies of open innovation, intermediation was practically absent. In recent years, many authors have revealed the importance of intermediaries to open innovation. These studies have laid the foundation for our understanding that an intermediary is a quite complex actor with sophisticated management principles (with its specific objectives, processes, competences, performance criteria, etc.). By studying intermediation in situations of high degrees of unknown, we find that the complexity of the intermediation management principles is even higher. For example, our cases involves the introduction of new actors into the ecosystem, stimulating innovation to overcome collective fixation, organising a legitimised collaborative working place, and addressing conflicts in creative ways. The intermediary becomes the architect of the ecosystem and is in charge of renewing the language of forms and values, inviting "entrepreneurs", dividing and coordinating the entrepreneurs' exploration work, and handling conflicts between them. Hence, this new intermediation role in the unknown is consistent with what Agogué et al. (2012) propose to be "the architect of the unknown".

Firms are increasingly relying on outside input and collaboration to revitalise their innovation processes to achieve not only incremental innovations, but also more radical innovation. There is a dilemma inherent in collective radical innovation, however. Radical innovation appears to require even more learning, well-managed collective exploration processes, longterm commitment and complex coordination - but open innovation teams can rely on neither the classical internal coordination capacities of the firm (learning, core competencies, collective ownership, common purpose, etc.) nor market mechanisms that fundamentally change existing entities. Hence, it appears that more coordination is needed and less 
coordination capacity is available. The "architect of the unknown" (Agogué et al. 2012) appears to resolve this dilemma in situations of high degrees of unknown. The existence of the "architect of the unknown" (ibid.) explains why open innovation also can be radical.

Our paper has described the properties of intermediation in the unknown and principles for how to manage it. Yet, we acknowledge that our study has several limitations, which in turn has implications for future research. First, our case selection was built on the heterogeneity of our cases. As such our four cases are facets of a quite new phenomenon - intermediation in the unknown. More theoretical work is required to propose an integrated model of not only the functions but also the type of intermediaries in the unknown (in terms of role, governance, and performance). Second, even if our cases were very contrasting, we focused mainly on organizations. As stated by Howells (2006), we are in need today for a broader understanding of intermediation that includes as well individuals, professional bodies, research councils, advisory bodies and trade unions (ibid). We therefore call for further research to identify more examples of intermediaries in the unknown and to better understand their management tools and doctrines when intermediaries are not organizations as such. Last, the introduction of the degree of unknown may not be a specific feature of innovation intermediaries, and might call into question contemporary work on radical innovation in complex and open contexts. Future research may therefore extend the notion of unknown as a contingency variable to study innovation dynamics.

\section{References}

Agogué, M., Cassotti, M., \& Kazakçi, A. (2011). The Impact of Examples on Creative Design: Explaining Fixation and Stimulation Effects, International Conference on Engineering Design, ICED'11: 12. Technical University of Denmark.

Agogué, M., Yström, A., \& Le Masson, P. (2013). Rethinking the role of intermediaries as an architect of collective exploration and creation of knowledge in open innovation. International Journal of Innovation Management, 17(02).

Becker, B. \& Gassmann, O. (2006). Gaining leverage effects from knowledge modes within corporate incubators. $R \& D$ Management, 36 (1), pp. 1-16 
Bergek, A., Jacobsson, S., Carlsson, B., Lindmark, S. \& Rickne, A. (2008). Analyzing the functional dynamics of technological innovation systems: A scheme of analysis. Research Policy, 37 (3), pp. 407-429

Berthet, E., Bretagnolle, V. \& Segrestin, B. (2012). Analyzing the Design Process of Farming Practices Ensuring Little Bustard Conservation: Lessons for Collective Landscape Management, Journal of Sustainable Agriculture, 36:3, 319-336

Bessant, J. \& Rush, H. (1995). Building Bridges for Innovation: The Role of Consultants in Technology Transfer. Research Policy, 24 (1), pp. 97-114.

Birkinshaw, J., Bouquet, C., \& Barsoux, J.-L. (2011). The Five Myths of Innovation. MIT Sloan Management Review, 52 (2), pp. 43-50.

Callon, M. (1994). Is Science a Public Good? Science, Technology \& Human Values, 19, pp. 395-424.

Choudhury, V., and Sabherwal, R. (2003) "Portfolios of Control in Outsourced Software Development Projects,” Information Systems Research, 14(3), pp. 291-314.

Diener, K., \& Piller, F. T. (2010). The Market for Open Innovation: Increasing the Efficiency and Effectiveness of the Innovation Process. Aachen, RWTH-TIM Group 2010.

Dorst K (2006) Design Problems and Design Paradoxes. Design Issues 22 (3):4-17.

Eisenhardt, K. M. (1989) "Building Theories from Case Study Research," Academy of Management Review, 14(4), pp. 532-550.

Fawcett, S. E., Jones, S. L., \& Fawcett, A. M. (2012). Supply Chain Trust: The Catalyst for Collaborative Innovation. Business Horizons, 55 (2): pp. 163-178.

Flyvbjerg, B. (2006) "Five Misunderstandings About Case-Study Research," Qualitative Inquiry, 12(2), pp. 219-245. 
Gassmann O., \& Becker, B. (2006). Towards a Resource-Based View of Corporate Incubators. International Journal of Innovation Management, 10 (1), pp. 19-45

Glucksberg, S. (1962). The Influence of Strength of Drive on Functional Fixedness and Perceptual Recognition. Journal of Experimental Psychology, 63, pp. 36-41.

Gianiodis, P., Ellis, S. C. \& Secchi, E. (2010). Advancing a Typology of Open Innovation. International Journal of Innovation Management, 14 (4), pp. 531- 572.

Grin J (2005) Reflexive modernization as a governance issue - or: designing and shaping Restructuration. In: Voss J-P, Bauknecht D, Kemp R (eds) Reflexive Governance for Sustainable Development. Edward Elgar, Cheltenham,

Hargadon, A. \& Sutton, R. I. (1997). Technology Brokering and Innovation in a Product Development Firm. Administrative Science Quarterly, 42 (4), pp. 716-749.

Hargadon, A. B. (1998). Firms as Knowledge Brokers: Lessons in Pursuing Continuous Innovation. California Management Review, 40 (3), pp. 209-227.

Hatchuel A (2002) Towards Design Theory and expandable rationality: the unfinished program of Herbert Simon. Journal of Management and Governance 5 (3-4):260-273.

Hatchuel, A., \& Weil, B. (2009). CK design theory: an advanced formulation. Research in engineering design, 19(4), 181-192.

Hatchuel A, Starkey K, Tempest S, Le Masson P (2010) Strategy as Innovative Design: An Emerging Perspective. Advances in Strategic Management 27:3-28.

Hatchuel, A., Le Masson, P., \& Weil, B. (2011). Teaching Innovative Design Reasoning: How C-K Theory Can Help to Overcome Fixation Effect. Artificial Intelligence for Engineering Design, Analysis and Manufacturing, 25 (1), pp. 77-92. 
Hekkert, M.P., Suurs, R.A., Negro, S.O., Kuhlmann, S. \& Smits, R. (2007). Functions of innovation systems: A new approach for analysing technological change. Technological Forecasting \& Social Change 74, pp. 413-432

Hoppe, H.C., \& Ozdenoren, E., (2005). Intermediation in Invention. International Journal of Industrial Organization 23 (5-6), pp. 483-503.

Howells, J. (2006). Intermediation and the Role of Intermediaries in Innovation. Research Policy, 35 (5), pp. 715-728.

Hevner AR, March S, T., Park J, Ram S (2004) Design Science in Information Systems Research. MIS Quarterly 28 (1):75-105.

Inkinen, T., \& Suorsa, K. (2010). Intermediaries in regional innovation systems: hightechnology enterprise survey from Northern Finland. European Planning Studies, 18(2), 169187.

Israel, P. (1998). Edison: A Life of Invention. New York: John Wiley ans Sons.

Jansson, D. G., \& Smith, S. M. (1991). Design Fixation. Design Studies, 12 (1), pp. 3-11.

Klerkx, L., Aarts, N., \& Leeuwis, C. (2010). Adaptive management in agricultural innovation systems: The interactions between innovation networks and their environment. Agricultural systems, 103(6), 390-400.

Klerkx, L. \& Leeuwis, C. (2008). Balancing Multiple Interests: Embedding Innovation Intermediation in the Agricultural Knowledge Infrastructure. Technovation, 28 (6), pp. 364378

Klerkx, L., \& Leeuwis, C. (2009). Establishment and Embedding of Innovation Brokers at Different Innovation System Levels: Insights from the Dutch agricultural sector. Technological Forecasting \& Social Change, 76 (6), 849-860.

Knight, F H. (1921) Risk, Uncertainty, and Profit. Boston: Houghton Mifflin. 
Le Masson, P., \& Weil, B. (2013). Design theories as languages of the unknown: insights from the German roots of systematic design (1840-1960). Research in Engineering Design, 24(2), 105-126.

Le Masson, P., Aggeri, F., Barbier, M., \& Caron, P. (2012). The Sustainable Fibres of Generative Expectation Management: The "building with hemp" Case Study. In M. Barbier, \& B. Elzen (Eds.), System Innovations, Knowledge Regimes, and Design Practices towards Transitions for Sustainable Agriculture: 226-251. Paris: INRA Editions.

Le Masson, P., Cogez, P., Felk, Y., \& Weil, B. (2012a). Absorptive Capacity for Radical Innovation: A Case Study in the Semiconductor Industry. Advances in Technology and Innovation Management, Vol. 1

Le Masson, P., Cogez, P., Felk, Y., \& Weil, B. (2012b). Revisiting Absorptive Capacity with a Design Perspective. International Journal of Knowledge Management Studies, Accepted, to be published.

Le Masson, P., Weil, B., Hatchuel, A., \& Cogez, P. (2012). Why aren't they Locked in Waiting Games? Unlocking Rules and the Ecology of Concepts in the Semiconductor Industry. Technology Analysis \& Strategic Management, 24 (6), pp. 617-630.

Lichtenthaler U. and Ernst H. (2008). Innovation Intermediaries: Why Internet Marketplaces for Technology Have Not Yet Met the Expectations, Creativity and Innovation Management, 17 (1), pp. 14-25

Löfsten, H. \& Lindelöf, P. (2002). Science Parks and the growth of new technology-based firms - Academic-industry links, innovation and markets. Research Policy, 31 (6), pp. 859876

Michaels, S. (2009). Matching knowledge brokering strategies to environmental policy problems and settings. Environmental Science \& Policy, 12(7), 994-1011.

McEvily, B., \& Zaheer, A. (1999). Bridging Ties: A Source of Firm Heterogeneity in Competitive Capabilities. Strategic Management Journal, 20 (12), pp. 1133-1156. 
Millard, A. 1990. Edison and the business of innovation. Baltimore and London: The Johns Hopkins University Press.

Nambisan, S., Bacon, J. \& Throckmorton, J. (2012). The Role of the Innovation Capitalist in Open, Research-Technology Management, 55 (3), pp. 49-57(9)

Nambisan, S. and M. Sawhney (2007). A Buyer's Guide to the Innovation Bazaar, Harvard Business Review, June, pp. 109-118.

Pink, D. H. (2009). Drive: The Surprising Truth About What Motivates Us. Riverhead Books.

Pollard, D. (2006). Innovation and Technology Transfer Intermediaries: A Systemic International Study, in Innovation through Collaboration (Advances in Interdisciplinary Studies of Work Teams, Vol. 12), Emerald Group Publishing Limited, pp. 137-174

Rittel HWJ (1972) On the Planning Crisis: Systems Analysis of the 'First and Second Generations'. Bedriftsokonomen 8:390-396.

Robinson, D. K. R., Le Masson, P., \& Weil, B. (2012). Waiting Games: Innovation impasses in situations of high uncertainty. Technology Analysis \& Strategic Management, 24 (6), pp. 543-548.

Santos, F. M., \& Eisenhardt, K. M. (2009). Constructing Markets and Shaping Boundaries: Entrepreneurial Power in Nascent Fields. Academy of Management Journal, 52 (4), pp. 643671.

Shohert, S., Prevezer, M., (1996). UK Biotechnology: Institutional Linkages, Technology Transfer and the Role of Intermediaries. R\&D Management 26 (3), pp. 283-298.

Schön DS (1990) The Design Process. In: Howard VA (ed) Varieties of Thinking. Essays from Harvard's Philosophy of Education Research Center. Routledge, New York, NY, pp 110-141 
Sieg, J. H., Wallin, M. W. and von Krogh, G. (2010). Managerial Challenges in Open Innovation: A Study of Innovation Intermediation in the Chemical Industry. $R \& D$ Management, 40 (3), pp. 281-291.

Simon HA (1969) The Sciences of the Artificial. M.I.T. Press, Cambridge, MA, USA

Stewart, J. \& Hyysalo, S. (2008). Intermediaries, Users and Social Learning in Technological Innovation. International Journal of Innovation Management, 12 (3), pp. 295-325.

Surowiecki, J. (2004). The Wisdom of Crowds: Why the Many are Smarter than the Few and how Collective Wisdom shapes Business, Economies, Societies, and Nations. New York: Doubleday.

Thursby, J.G., Jensen, R. \& Thursby, M.C. (2001). Objectives, Characteristics and Outcomes of University Licensing: A Survey of Major U.S. Universities. Journal of Technology Transfer, 26, pp. 59-72

Turpin, T., Garrett-Jones, S. \& Rankin, N. (1996). Bricoleurs and boundary riders: managing basic research and innovation knowledge networks. $R \& D$ Management, 26 (3), pp. 267-282

van Lente, H. v., Hekkert, M., Smits, R. \& Waveren, B. v. (2003). Roles of Systemic Intermediaries in Transition Processes. International Journal of Innovation Management, 7 (3), pp. 247-279.

Voelpel, S. C., Dous, M., \& Davenport, T. H. 2005. Five Steps to Creating a Global Knowledge-Sharing System: Siemens' ShareNet. Academy of Management Executive, 15(2), pp. 9-24.

von Foerster H (1991) Ethics and Second-Order Cybernetics. In: Rey Y, Prieur B (eds) Systemes, ethiques: perspectives en thérapie familiale. ESF éditeur, Paris, pp 41-54

Winch, G. H. \& Courtney, R. 2007. The Organization of Innovation Brokers: An International Review. Technology Analysis \& Strategic Management, 19 (6), pp. 747-763. 
Yin, R. K. (2009). Case Study Research: Design and Methods (Fourth Edition). In L. Bickman \& D. J. Rog, (Eds.) Applied Social Research Methods Series, Vol. 5. Sage Publications, Inc. 